\title{
Controlled Atmosphere Storage for Pomegranates (Punica granatum L.): Benefits over Regular Air Storage
}

\author{
Harwinder Singh Sidhu', Juan Carlos Díaz-Pérez ${ }^{2}$, and Daniel MacLean \\ Department of Horticulture, University of Georgia, 2360 Rainwater Road, \\ Tifton, GA 31793- 5766
}

Additional index words. Mediterranean crops, humid climate, fruit quality, pomegranate cultivar evaluation, antioxidants

\begin{abstract}
Controlled atmosphere (CA) storage has been observed to prolong the shelf life of fresh produce. The objective of this study was to determine whether $\mathrm{CA}$ storage performed better than regular air (RA) storage in maintaining fruit quality of six pomegranate (Punica granatum L.) cultivars grown in the state of Georgia. Pomegranate fruit produced in Ty Ty, GA in 2010 and 2011 were stored in $\mathrm{CA}\left[5 \% \mathrm{CO}_{2}+3 \% \mathrm{O}_{2}, 5{ }^{\circ} \mathrm{C}\right.$, $90 \%$ to $95 \%$ relative humidity (RH)] or $\mathrm{RA}\left(5{ }^{\circ} \mathrm{C}, 90 \%\right.$ to $\left.95 \% \mathrm{RH}\right)$ for 3 months. Pomegranate whole fruit and juice were evaluated for various physical and chemical attributes at the end of storage. Fruit differed by cultivar for rind smoothness, fruit cracking, disease incidence, and chilling injury (CI). Fruit stored in CA had a smoother and less shriveled rind, lower CI, fewer disease severity symptoms, and thus better quality than fruit stored in RA. Fruit rind color, total soluble solids (TSS), titratable acidity (TA), and anthocyanin content in fruit juice were unaffected by storage method. The results showed that pomegranate fruit quality was better sustained under $C A$ compared with RA storage.
\end{abstract}

Pomegranate (Punica granatum L.), a species of the Punicaceae family, is a fruit plant native to the region extending from Iran to the Himalayas (Holland et al., 2009). It is believed to be among the first fruit tree cultivated by humans in around $4000 \mathrm{BC}$ in the Middle East. Pomegranate fruit are consumed fresh and are used for the production of juice, wine, and syrup. Increased awareness about the health benefits of the pomegranate tree and its products has possibly contributed to the worldwide increase in its production (Basu and Penugonda, 2009). Arils are the edible portion of fruit; they are the juicy pulp around the seeds formed from ovules present in the ovary of fertilized fruit (Shulman et al., 1984). Storing pomegranates adequately postharvest is crucial to maintaining a consistent supply of high-quality fruit in the marketplace.

Fruit quality comprises the physical and chemical attributes of fruit. Fruit physical attributes include fruit weight, rind smoothness, and rind shriveling, and are influenced by the presence of fruit physiologic disorders (e.g., sunscald), fruit diseases, and fruit mechanical damage. Fruit physical attributes may be affected by tree maturity, environmental conditions during fruit development, fruit maturity at time of harvest, and fruit diseases (Considine and Brown, 1981; Elyatem and Kader, 1984; Weerakkody et al., 2010). Fruit chemical attributes such

Received for publication 26 Feb. 2019. Accepted for publication 27 Mar. 2019.

${ }^{1}$ Graduate student.

${ }^{2}$ Corresponding author. E-mail: jcdiaz@uga.edu. as TSS, TA, and anthocyanin content may also be influenced by the same factors as the physical attributes (Kulkarni and Aradhya, 2005).

Postharvest storage conditions also affect fruit quality. Inadequate storage conditions are responsible for significant economic losses. High rates of fruit weight loss, resulting mainly from fruit water loss, may occur under high temperatures or low RH (Díaz-Pérez, 2019). A 5\% fruit weight loss in pomegranate leads to visible fruit rind shriveling (Palou et al., 2007). Decay by pathogens such as Botrytis cinerea, Alternaria spp., and Aspergillus spp. causes significant fruit loss during storage (Kader and Mitcham, 1999). CI, observed as the development of browning in pericarp, arils, and seeds, can happen while storing fruit at less than $5{ }^{\circ} \mathrm{C}$ under standard refrigerated conditions for more than 2 months. Moreover, chilled fruit become sensitive to fungal decay (Elyatem and Kader, 1984).

CA storage extends the shelf life of many tropical and subtropical fruit (Kader, 2003; Yahia, 2006). In CA, decreased $\mathrm{O}_{2}$ and increased $\mathrm{CO}_{2}$ concentrations, along with low temperatures reduce fruit respiration rate and ethylene production, suppress or delay senescence processes, and ultimately prolong postharvest shelf life (Gómez and Artés, 2004; Kader and Watkins, 2000). Conditions in CA storage affect both host fruit and any pathogens on it. In CA storage, fruit show reduced decay either because the fruit have improved health that enables them to resist pathogen attacks or because CA conditions reduce pathogen ability to grow and spread (Conway et al., 2007; Lidster et al., 1983;
Yackel et al., 1971). Storing pomegranate fruit at $2 \%$ to $4 \% \mathrm{O}_{2}$ in air at 2 to $6{ }^{\circ} \mathrm{C}$ has been observed to inhibit CI (Ben-Arie, 1986). Reductions in fruit water loss, CI, and fungal decay have been observed in pomegranate kept in CA storage (Artés et al., 1996; Caleb et al., 2012). Similarly, CA has outperformed modified packaging in preventing fruit decay in loquat (Eriobotrya japonica Lindl.) (Ding et al., 2006).

Recommendations for pomegranate storage have been cultivar specific (Küpper et al., 1995). Although 2 to $6{ }^{\circ} \mathrm{C}$ is the typical storage temperature for regular pomegranates, storage at $10{ }^{\circ} \mathrm{C}$ is the minimum safe storage temperature for sweet pomegranates. Storage at $10{ }^{\circ} \mathrm{C}$, however, is not effective in reducing fruit fungal decay (Palou et al., 2007). Pomegranates may show high postharvest losses as a result of fruit water loss and decay during storage. Thus, adequate postharvest storage is crucial for a reliable market supply of high-quality pomegranate fruit. There is limited information on postharvest storage of pomegranates grown in the southeastern United States. The objective of this study was to determine the effects of CA storage on the physical and chemical properties of pomegranate fruit of various cultivars grown in the state of Georgia.

\section{Materials and Methods}

Pomegranate fruit from six cultivarsAfganski, Crab, Cranberry, Entek-habi-saveh, Kaj-acik-anor, and Salavatski-were harvested on 6 Oct. 2010 (PF2010) and 5 Oct. 2011 (PF2011) from University of Georgia Ponder Farm (PF), Ty Ty, GA. Fruit were brought to the Vidalia Onion Research Laboratory, University of Georgia Tifton Campus. Four fruit from each cultivar, free from physical damage and decay, were kept in either RA storage $\left(5{ }^{\circ} \mathrm{C}, 90 \%\right.$ to $\left.95 \% \mathrm{RH}\right)$ or $\mathrm{CA}$ storage $\left(3 \% \mathrm{O}_{2}, 5 \% \mathrm{CO}_{2}, 5{ }^{\circ} \mathrm{C}, 90 \%\right.$ to $95 \%$ $\mathrm{RH})$ for 3 months. Four fruit from each cultivar under one storage condition comprised the experimental unit. At the end of storage, fruit were evaluated for physical (whole fruit) and chemical (juice) quality attributes. Rainfall (measured in centimeters) and maximum daily temperature (measured in degrees Celsius) from 1 Apr. to 30 Sept. in both 2010 and 2011 for Tifton, GA, was sourced from Climate Data Online at National Centers for Environmental Information (www.ncdc.noaa.gov).

\section{Fruit quality}

After a 3-month storage, fruit were removed to room temperature, then weighed and graded visually. Fruit rind smoothness was graded as 5, high rind smoothness; 4, moderately high; 3 , moderate, rind with rashes or patches; 2, moderately low, rough rind with major portion of fruit covered with rashes; and 1, low rind smoothness, very rough rind. Fruit imperfections such as rind shriveling (1, no shriveling; 2 , mild shriveling, fruit is marketable; 3 , moderate shriveling, fruit is not marketable; 4 , severe shriveling, fruit 
is not marketable), fruit cracking ( 1 , no cracking; 2 , mild cracking with very thin cracks, possibly superficial, fruit marketable; 3 , moderate cracking, small but wide cracks, arils visible, fruit unmarketable; 4 , severe cracking, long, wide cracks, fruit unmarketable), sunscald (1, no sunscald; 2 , mild sunscald, sunscald damage on less than $25 \%$ fruit area, easily visible sunscald damage; 3 , moderate sunscald, $25 \%$ to $50 \%$ fruit area with sunscald; 4, severe sunscald, more than 50\% fruit surface area with sunscald damage, unmarketable fruit, sunburn), and Cercospora severity $(1$, negligible, $0-2$ spots; 2 , mild, 5-10 spots scattered on fruit surface, fruit marketable; 3 , moderate, more than 10 spots, unmarketable fruit; 4 , high, more than one fourth of fruit rind covered with spots, unmarketable fruit) were recorded for each fruit. After cutting the fruit open, CI (1, no CI; 2, mild CI, less than 10\% fruit arils affected, fruit marketable; 3, moderate CI, $10 \%-50 \%$ fruit arils show CI, fruit unsuitable for marketing; 4 , severe CI, more than $50 \%$ of arils affected, fruit unmarketable) and decay caused by Botryosphaeria spp. and Alternaria spp. (1, no disease damage, fruit marketable; 2 , mild disease damage, less than $25 \%$ of fruit affected, disease not visible outside from the rind; 3 , moderate disease damage, $25 \%$ to $50 \%$ of fruit damaged, disease symptoms visible from outside and fruit unmarketable; 4, high disease damage, more than $50 \%$ fruit damaged, unmarketable fruit) were graded.

Fruit color. A CR-400 (8-mm aperture, D65 illuminant) handheld colorimeter (Konica Minolta, Ramsey, NJ) was used to measure fruit rind color. Five color readings were taken per fruit. Color was measured as $\mathrm{L}^{*}, \mathrm{a}^{*}$, $b^{*}$. The value of $L^{*}$ describes the degree of darkness or lightness with $\mathrm{L}=0$ being black and $\mathrm{L}=100$ being white. The $\mathrm{b}^{*}$ value refers to the colors in the range yellow to blue. Value $a^{*}$ refers to colors ranging from redpurple to blue-green. Chroma and hue angle were calculated from the $L^{*}, a^{*}$, and $b^{*}$ values using Spectramagic NX 2.03 (Konica Minolta) software. Chroma represents richness of color on a 0 to 60 scale, with 0 being gray and 60 being the true color. Hue angle represents dominant color wavelength.

\section{Fruit chemical attributes}

TSS/TA ratio. A sample of 50 arils per fruit were weighed (in grams per 50 arils) and squeezed in a cheese cloth to extract the juice. Juice was weighed (in grams per 50 arils) to calculate percentage juice content (juice/ weight ratio) of arils. TSS was measured using a refractometer (Brix-stix digital handheld refractometer; Cole-Parmer, Livermore, CA), which was calibrated with distilled water. TA was determined using an automatic titrator (DL-15; Mettler Toledo, Columbus, $\mathrm{OH}$ ) by using $500 \mu \mathrm{L}$ juice diluted with $25 \mathrm{~mL}$ water. The juice sample was titrated to $\mathrm{pH} 8.2$ using $0.1 \mathrm{M} \mathrm{NaOH}$ after recording the initial $\mathrm{pH}$. TA was expressed as a percentage of malic acid present in juice.

Anthocyanins. Anthocyanins in pomegranate juice were separated using highperformance liquid chromatography (HPLC) (1200 Series, model g1316; Agilent Technologies, Santa Clara, CA) equipped with a XDB-C18 (Zorbax Eclipse, Agilent Technologies) $3.5-\mu \mathrm{m}$ column. Juice samples were centrifuged (Allegra 25R centrifuge; Beckman Coulter, Atlanta, GA) at $25,155 \mathrm{~g}$ for $30 \mathrm{~min}$ at $4{ }^{\circ} \mathrm{C}$. Supernatant of $0.75 \mathrm{~mL}$ was added to the HPLC tubes. Flow rate was maintained at $0.4 \mathrm{~mL} \cdot \mathrm{min}^{-1}$, with solution $\mathrm{A}$ as $5 \%$ formic acid and solution B as $95 \%$ acetonitrile. The gradient used ran from $5 \%$ $\mathrm{A}$ and $95 \% \mathrm{~B}$ at $2 \mathrm{~min} ; 15 \% \mathrm{~A}, 85 \% \mathrm{~B}$ at 19 $\min ; 20 \% \mathrm{~A}, 80 \% \mathrm{~B}$ at $20 \mathrm{~min} ; 100 \% \mathrm{~A}$ at $21 \mathrm{~min} ; 100 \% \mathrm{~A}$ at $24 \mathrm{~min} ; 5 \% \mathrm{~A}, 95 \% \mathrm{~B}$ at $24.9 \mathrm{~min}$; and $5 \% \mathrm{~A}, 95 \% \mathrm{~B}$ at $28 \mathrm{~min}$. The runtime was $28 \mathrm{~min}$ per sample. Five anthocyanins were observed at a spectral scan of $520 \mathrm{~nm}$. Anthocyanin concentrations were determined using a standard curve and results are expressed as cyanidin, 3-glucoside equivalent (measured in micrograms per gram in arils).

\section{Statistical design and analysis}

The experiment was a completely randomized design. The treatments consisted of six cultivars $\times$ two storage (RA and CA) combinations. Analysis of variance was carried out using SAS Enterprise 9.2 (SAS Institute, Cary, SC) for all response variables. Whenever interactions between main factors were significant, effects of main factors are not discussed separately.

\section{Results}

Physical attributes. All fruit physical attributes varied by cultivar in both 2010 (Table 1) and 2011 (Table 2), except for sunscald, and fruit weight (in 2011 only). Average fruit weight ranged between 177 and $284 \mathrm{~g}$ in 2010 (Table 1), and 230 and $291 \mathrm{~g}$ in 2011 (Table 2). Fruit from 'Crab' and 'Salavatski' had among the smoothest fruit rind. 'Crab' in 2010 and 'Salavatski' in 2010 and 2011 had the least fruit shriveling (Tables 1 and 2). Fruit cracking among cultivars varied between years. In 2010, fruit cracking severity was greatest in 'Crab' (Table 1); in 2011, fruit cracking was greatest in 'Afganski', whereas 'Crab' had reduced fruit cracking (Table 2). Sunscald severity was similar among cultivars in both years (Tables 1 and 2). In 2010, cultivars Afganski, Entek-habisaveh, and Kaj-acik-anor had the greatest fruit disease severity by Cercospora (Table 1), whereas in 2011, 'Afganski' had the greatest disease severity. In 2011, 'Cranberry' had the highest severity by Alternaria/ Botryosphaeria whereas 'Kaj-acik-anor' and 'Salavatski' had the lowest severity by Alternaria/Botryosphaeria. 'Cranberry' and 'Kaj-acik-anor' had the least CI whereas 'Afganski' had the greatest CI after storage (Table 2). Overall, 13\% of fruit stored in CA

Table 1. Physical attributes and disease severity of pomegranate fruit of various cultivars immediately after 3 months of storage in either a controlled atmosphere [CA; $5 \% \mathrm{CO}_{2}$ and $3 \% \mathrm{O}_{2}, 5^{\circ} \mathrm{C}$, and $90 \%$ to $95 \%$ relative humidity $(\mathrm{RH})$ ] or in regular air (RA; $5{ }^{\circ} \mathrm{C}$ and $90 \%$ to $95 \% \mathrm{RH}$ ), harvested from Ponder Farm, Ty Ty, GA, in 2011. Rows labeled Cultivar, Storage, and Cultivar $\times$ storage include the $P$ values.

\begin{tabular}{|c|c|c|c|c|c|c|}
\hline & Fruit wt $(\mathrm{g})$ & Smoothness $^{\mathrm{z}}$ & Shriveling $^{y}$ & Cracking $^{x}$ & Sunscald $^{\mathrm{w}}$ & $\mathrm{CeSev}^{v}$ \\
\hline \multicolumn{7}{|l|}{ Cultivar } \\
\hline Crab & $177 \mathrm{~B}$ & $3.1 \mathrm{AB}$ & $2.4 \mathrm{~B}$ & $1.8 \mathrm{~A}$ & $2.1 \mathrm{~A}$ & $2.2 \mathrm{~B}$ \\
\hline Cranberry & $296 \mathrm{~A}$ & $2.7 \mathrm{~B}$ & $2.1 \mathrm{BC}$ & $1.4 \mathrm{AB}$ & $2.4 \mathrm{~A}$ & $2.4 \mathrm{~B}$ \\
\hline Kaj-acik-anor & $244 \mathrm{AB}$ & $2.8 \mathrm{~B}$ & $1.7 \mathrm{CD}$ & $1.3 \mathrm{~B}$ & $1.9 \mathrm{~A}$ & $3.0 \mathrm{~A}$ \\
\hline Salavatski & $284 \mathrm{~A}$ & $3.8 \mathrm{~A}$ & $1.4 \mathrm{D}$ & $1.1 \mathrm{~B}$ & $1.8 \mathrm{~A}$ & $2.4 \mathrm{~B}$ \\
\hline \multicolumn{7}{|l|}{ Storage } \\
\hline \multicolumn{7}{|l|}{ Significance } \\
\hline Cultivar & $<0.0001$ & 0.0002 & $<0.0001$ & 0.0006 & 0.07 & $<0.0001$ \\
\hline Storage & 0.7716 & 0.4565 & 0.0336 & 0.1895 & 0.3258 & $<0.0001$ \\
\hline Cultivar $\times$ storage & 0.1333 & 0.0586 & 0.4882 & 0.5412 & 0.9851 & 0.2327 \\
\hline
\end{tabular}

${ }^{\mathrm{z}}$ Rind smoothness on a 1 to 5 scale, where $1=$ rough and $5=$ smooth.

${ }^{\mathrm{y}}$ Rind shriveling on a 1 to 4 scale, where $1=$ no shriveling and $4=$ severe shriveling, unmarketable.

${ }^{\mathrm{x}}$ Fruit cracking on a 1 to 4 scale, where $1=$ no cracking and $4=$ severe cracking, fruit split open on one side.

${ }^{\mathrm{w}}$ Sunscald on a 1 to 4 scale, where $1=$ no sunscald and $4=$ severe sunscald.

${ }^{v}$ Cercospora severity on a 1 to 4 scale, where $1=$ no disease symptoms and $4=$ disease symptoms rendering fruit unmarketable.

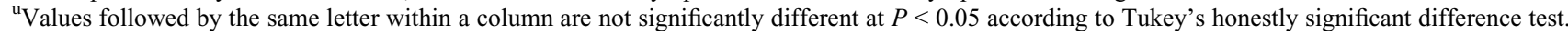


showed fruit decay, whereas in RA storage, $70 \%$ of the fruit had fruit decay. In 2010 , fruit stored in CA storage had reduced shriveling and reduced severity by Cercospora (Table 1). In 2011, fruit stored in CA had smoother fruit rind and were less shriveled than fruit stored in RA. Sunscald, disease severity by Cercospora and Alternarial Botryosphaeria, and CI were reduced in fruit stored in CA (Table 2). Fruit fresh weight and fruit cracking severity were unaffected by storage method.

Chemical attributes. Aril juice content was unaffected by cultivar and storage conditions in both years (Table 3), with an average of $78 \%$ in 2010 and $76.5 \%$ in 2011 . Values of TSS were among the highest in 'Crab' in both years. TA was similar among cultivars in 2010; TA was greatest in 'Afganski' and 'Kaj-acik-anor' in 2011. The TSS/ TA ratio was greatest in 'Cranberry' and 'Salavatski' in 2010 and in 'Crab' in 2011, although not significantly different from that of 'Cranberry'. Among cultivars, the juice $\mathrm{pH}$ of 'Entek-habi-saveh' was the highest in 2010, whereas juice $\mathrm{pH}$ of 'Crab' and 'Salavatski' were the highest in 2011. Juice

Table 2. Physical attributes and disease severity of pomegranate fruit of various cultivars immediately after 3 months of storage in either a controlled atmosphere [CA; $5 \% \mathrm{CO}_{2}$ and $3 \% \mathrm{O}_{2}, 5^{\circ} \mathrm{C}$, and $90 \%$ to $95 \%$ relative humidity $(\mathrm{RH})$ ] or in regular air (RA; $5{ }^{\circ} \mathrm{C}$ and $90 \%$ to $95 \% \mathrm{RH}$ ), harvested from Ponder Farm, Ty Ty, GA, in 2011. Rows labeled Cultivar, Storage, and Cultivar $\times$ storage include the $P$ values.

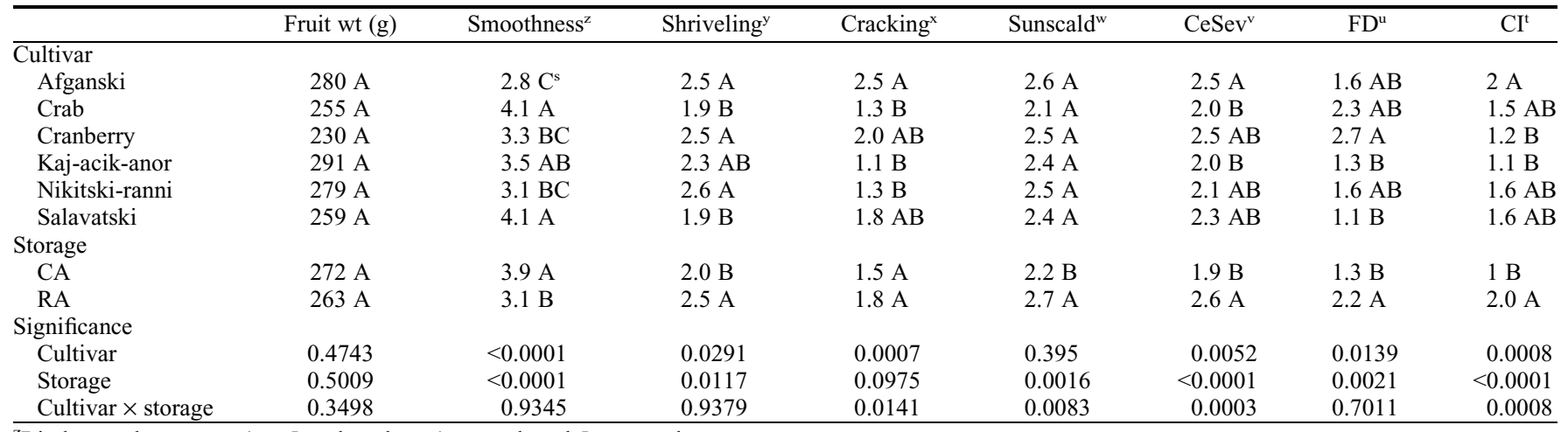

${ }^{\mathrm{z}}$ Rind smoothness on a 1 to 5 scale, where $1=$ rough and $5=$ smooth.

${ }^{\mathrm{y}}$ Rind shriveling on a 1 to 4 scale, where $1=$ no shriveling and $4=$ severe shriveling, unmarketable.

${ }^{\mathrm{x}}$ Fruit cracking on a 1 to 4 scale, where $1=$ no cracking and $4=$ severe cracking, fruit split open on one side.

${ }^{\mathrm{w}}$ Sunscald on a 1 to 4 scale, where $1=$ no sunscald and $4=$ severe sunscald.

${ }^{\mathrm{v}}$ Cercospora severity on a 1 to 4 scale, where $1=$ no disease symptoms and $4=$ disease symptoms rendering fruit unmarketable.

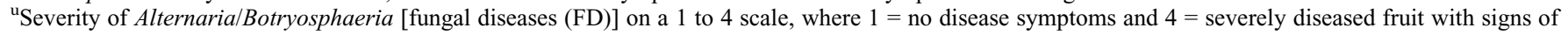
pathogen, unmarketable fruit.

${ }^{t}$ Chilling injury $(\mathrm{CI})$ on a 1 to 4 scale, where $1=$ no $\mathrm{CI}$ and $4=$ severe CI, with more than half of arils affected, fruit unmarketable

${ }^{\mathrm{s}}$ Values followed by the same letter within a column are not significantly different at $P<0.05$ according to Tukey's honestly significant difference test.

Table 3. Chemical attributes of pomegranate fruit of various cultivars immediately after 3 months of storage in either a controlled atmosphere [CA; $5 \% \mathrm{CO}_{2}$ and $3 \% \mathrm{O}_{2}, 5{ }^{\circ} \mathrm{C}$, and $90 \%$ to $95 \%$ relative humidity (RH)] or in regular air (RA; $5{ }^{\circ} \mathrm{C}$ and $90 \%$ to $95 \% \mathrm{RH}$ )], harvested from Ponder Farm, Ty Ty, GA, in 2010 and 2011. Rows labeled Cultivar, Storage, and Cultivar $\times$ storage include the $P$ values.

\begin{tabular}{|c|c|c|c|c|c|}
\hline & $\mathrm{JC}(\%)$ & TSS (\%) & TA ( $\%$ malic acid $)$ & TSS/TA & $\mathrm{pH}$ of fruit juice \\
\hline \multicolumn{6}{|l|}{$\overline{2010}$} \\
\hline Afganski & $76 \mathrm{~A}$ & $14.7 \mathrm{BC}^{\mathrm{z}}$ & $3.0 \mathrm{~A}$ & $6.8 \mathrm{AB}$ & $2.9 \mathrm{~B}$ \\
\hline Crab & $82 \mathrm{~A}$ & $15.5 \mathrm{~A}$ & $2.6 \mathrm{~A}$ & $6.7 \mathrm{AB}$ & $3.1 \mathrm{AB}$ \\
\hline Entek-habi-saveh & $73 \mathrm{~A}$ & $15.5 \mathrm{~A}$ & $3.3 \mathrm{~A}$ & $5.7 \mathrm{AB}$ & $3.2 \mathrm{~A}$ \\
\hline Kaj-acik-anor & $80 \mathrm{~A}$ & $15.3 \mathrm{AB}$ & $3.3 \mathrm{~A}$ & $5.2 \mathrm{~B}$ & $2.9 \mathrm{~B}$ \\
\hline Salavatski & $78 \mathrm{~A}$ & $15.4 \mathrm{AB}$ & $2.6 \mathrm{~A}$ & $8.2 \mathrm{~A}$ & $3.1 \mathrm{AB}$ \\
\hline RA & $76 \mathrm{~A}$ & $14.8 \mathrm{~B}$ & $2.1 \mathrm{~B}$ & $9.0 \mathrm{~A}$ & $3.0 \mathrm{~A}$ \\
\hline \multicolumn{6}{|l|}{ Significance } \\
\hline Cultivar & 0.0683 & 0.0002 & 0.4089 & 0.0037 & 0.0472 \\
\hline Storage & 0.0627 & $<0.0001$ & $<0.0001$ & $<0.0001$ & 0.3552 \\
\hline Cultivar $\times$ storage & 0.3645 & 0.0002 & 0.0002 & $<0.0001$ & 0.0504 \\
\hline \multicolumn{6}{|l|}{2011} \\
\hline \multicolumn{6}{|l|}{ Cultivar } \\
\hline Salavatski & $76 \mathrm{~A}$ & $15 \mathrm{~B}$ & $1.19 \mathrm{~B}$ & $12.8 \mathrm{~B}$ & $5.81 \mathrm{~A}$ \\
\hline \multicolumn{6}{|l|}{ Storage } \\
\hline $\mathrm{CA}$ & $76 \mathrm{~A}$ & $15.2 \mathrm{~A}$ & $1.23 \mathrm{~B}$ & $13.1 \mathrm{~A}$ & $5.84 \mathrm{~A}$ \\
\hline RA & $77 \mathrm{~A}$ & $15 \mathrm{~A}$ & $1.41 \mathrm{~A}$ & $11.3 \mathrm{~B}$ & $5.54 \mathrm{~B}$ \\
\hline \multicolumn{6}{|l|}{ Significance } \\
\hline Cultivar & 0.829 & $<0.0001$ & $<0.0001$ & $<0.0001$ & 0.0006 \\
\hline Storage & 0.534 & 0.1874 & 0.0149 & 0.0001 & $<0.0001$ \\
\hline Cultivar $\times$ storage & 0.9964 & 0.0317 & 0.7113 & 0.219 & 0.0006 \\
\hline
\end{tabular}

${ }^{\mathrm{z}}$ Values followed by the same letter within a column are not significantly different at $P<0.05$ according to Tukey's honestly significant difference test.

$\mathrm{JC}=$ juice content of arils by weight; TSS $=$ total soluble solids; TA $=$ titratable acidity. 
content was unaffected by storage method in both years. Chemical attributes were affected inconsistently by storage method.

Juice anthocyanin contents varied by cultivar but did not vary by storage condition in both 2010 (Table 4) and 2011 (Table 5). Delphinidin 3,5-diglucoside content was among the highest in 'Crab' in both years (Tables 4 and 5). Cyanidin 3,5-diglucoside was highest in 'Crab' in both years. Petunidin 3-glucoside, cyanidin 3-glucoside, pelargonidin 3-glucoside, and total anthocyanins had among the highest values in 'Kaj-acik-anor' in both years.

Fruit rind color lightness, hue angle, and chroma varied by cultivar, which was expected given the range of rind color displayed in harvested fruit (Table 6). 'Afganski', 'Crab', and 'Cranberry' had reduced hue angle values (31.2-33.6), which indicates their fruit rind was reddish, whereas 'Entekhabi-saveh', 'Kaj-acik-anor', and 'Salavatski' had values ranging from 51.6-53.8, indicating their fruit rind was yellowish.
There were no differences in color attributes as a result of storage conditions, although a cultivar-storage interaction was observed for lightness and hue angle.

\section{Discussion}

In our study, fruit quality was affected by cultivar. Weather conditions during maturity may affect cultivars differently, with the produce from one year being affected more compared with another (Kays, 1999). Year 2011 was dry during pomegranate maturity, possibly decreasing fruit quality in comparison with 2010 (Fig. 1). Moisture, heat, and other abiotic stresses during maturity affect fruit quality in apple, banana, citrus, cucumber, muskmelon, peach, pineapple, olive, and many other species (Kays, 1999).

CA storage had a positive effect on most of the fruit attributes. CA storage has been observed to preserve fruit rind quality and prolong storage shelf life of fruit (Özgen et al., 2002). Rind shriveling results from moisture loss and could account for a sizeable portion of total fruit weight loss (Elyatem and Kader, 1984). Rind of pomegranate is very porous and allows rapid loss of moisture. Fruit quality can be maintained with a prestorage wax treatment, but that incurs an added cost (Barman et al., 2011). Fruit weight loss from transpiration further leads to fruit wilting and desiccation. Greater fruit quality under CA storage than RA storage is a result of mitigation of fruit deterioration processes (D'Aquino et al., 2010).

Our finding of reduced fruit decay in CA storage compared with ambient air storage is consistent with reports on other fruit. Apples stored under CA storage had less fungal damage compared with ambient air-stored apples when evaluated after keeping at $20^{\circ} \mathrm{C}$ for a few weeks following cold storage (Børve and Stensvand, 2016). Fungal damage affects fruit quality directly because rind smoothness is affected by the incidence of disease. There was reduced damage from fungal diseases under $\mathrm{CA}$ than under RA

Table 4. Anthocyanins contents of pomegranate fruit of various cultivars, immediately after three mo. of storage in either $\mathrm{CA}\left[\mathrm{CA}\left(5 \% \mathrm{CO}_{2}\right.\right.$ and $3 \% \mathrm{O}_{2}, 5{ }^{\circ} \mathrm{C}$ and $90 \%$ to $95 \% \mathrm{RH})$ ] or regular air [RA $\left(5{ }^{\circ} \mathrm{C}\right.$ and $90 \%$ to $\left.95 \% \mathrm{RH}\right)$ ], harvested from Ponder Farm, Ty Ty, GA in 2010 . Rows labeled Cultivar, Storage, and Cultivar $\times$ storage include the $P$ values.

\begin{tabular}{|c|c|c|c|c|c|c|}
\hline & $\begin{array}{c}\text { De-3-5-digl } \\
\left(\mu \mathrm{g} \cdot \mathrm{g}^{-1} \text { aril wt }\right)\end{array}$ & $\begin{array}{c}\text { Cy-3-4-digl } \\
\left(\mu \mathrm{g} \cdot \mathrm{g}^{-1} \text { aril wt }\right)\end{array}$ & $\begin{array}{c}\text { Pet-3-gl } \\
\left(\mu \mathrm{g} \cdot \mathrm{g}^{-1} \text { aril wt }\right)\end{array}$ & $\begin{array}{c}\mathrm{Cy}-3-\mathrm{gl} \\
\left(\mu \mathrm{g} \cdot \mathrm{g}^{-1} \text { aril wt }\right)\end{array}$ & $\begin{array}{c}\text { Pel-3-gl } \\
\left(\mu \mathrm{g} \cdot \mathrm{g}^{-1} \text { aril wt }\right)\end{array}$ & $\begin{array}{c}\text { Total }^{\mathrm{z}} \\
\left(\mu \mathrm{g} \cdot \mathrm{g}^{-1} \text { aril wt }\right)\end{array}$ \\
\hline Afganski & $93 C^{y}$ & $364 \mathrm{C}$ & $95 \mathrm{AB}$ & $499 \mathrm{AB}$ & $37 \mathrm{AB}$ & $1089 \mathrm{~B}$ \\
\hline Crab & $387 \mathrm{~A}$ & $1015 \mathrm{~A}$ & $93 \mathrm{AB}$ & $398 \mathrm{BC}$ & $36 \mathrm{AB}$ & $1930 \mathrm{~A}$ \\
\hline Entek-habi-saveh & $130 \mathrm{BC}$ & $481 \mathrm{BC}$ & $61 \mathrm{~B}$ & $334 \mathrm{BC}$ & $14 \mathrm{BC}$ & $1020 \mathrm{~B}$ \\
\hline Kaj-acik-anor & $266 \mathrm{AB}$ & $733 \mathrm{AB}$ & $145 \mathrm{~A}$ & $773 \mathrm{~A}$ & $41 \mathrm{~A}$ & $1958 \mathrm{~A}$ \\
\hline Salavatski & $51 \mathrm{C}$ & $380 \mathrm{C}$ & $30 \mathrm{~B}$ & $304 \mathrm{BC}$ & $13 \mathrm{C}$ & $777 \mathrm{~B}$ \\
\hline \multicolumn{7}{|l|}{ Significance } \\
\hline Cultivar & $<0.0001$ & $<0.0001$ & 0.0002 & $<0.0001$ & 0.0002 & $<0.0001$ \\
\hline Storage & 0.2144 & 0.8032 & 0.6275 & 0.5699 & 0.1516 & 0.9946 \\
\hline Cultivar $\times$ storage & 0.9856 & 0.5924 & 0.7304 & 0.1877 & 0.8641 & 0.6807 \\
\hline
\end{tabular}

${ }^{\mathrm{z}}$ Total anthocyanin content.

${ }^{\mathrm{y}}$ Values followed by the same letter within a column are not significantly different at $P<0.05$ according to Tukey's honestly significant difference test. De-3-5-digl = delphinidin 3,5-diglucoside; Cy-3-4-digl = cyanidin 3,5-diglucoside; Pet-3-gl = petunidin 3-glucoside; Cy-3-gl = cyanidin 3-glucoside; Pel-3-gl = pelargonidin 3-glucoside.

Table 5. Anthocyanin content of pomegranate fruit of various cultivars immediately after 3 months of storage in either a controlled atmosphere $\left[\mathrm{CA} ; 5 \% \mathrm{CO}_{2}\right.$ and $3 \% \mathrm{O}_{2}, 5^{\circ} \mathrm{C}$, and $90 \%$ to $95 \%$ relative humidity (RH)] or regular air (RA; $5{ }^{\circ} \mathrm{C}$ and $90 \%$ to $95 \% \mathrm{RH}$ ), harvested from Ponder Farm, Ty Ty, GA, in 2011 . Rows labeled Cultivar, Storage, and Cultivar $\times$ storage include the $P$ values.

\begin{tabular}{|c|c|c|c|c|c|c|}
\hline & $\begin{array}{c}\text { De-3-5-dig1 } \\
\left(\mu \mathrm{g} \cdot \mathrm{g}^{-1} \text { aril wt }\right)\end{array}$ & $\begin{array}{c}\text { Cy-3-4-digl } \\
\left(\mu \mathrm{g} \cdot \mathrm{g}^{-1} \text { aril wt }\right)\end{array}$ & $\begin{array}{c}\text { Pet-3-gl } \\
\left(\mu \mathrm{g} \cdot \mathrm{g}^{-1} \text { aril weight }\right)\end{array}$ & $\begin{array}{c}\mathrm{Cy}-3-\mathrm{gl} \\
\left(\mu \mathrm{g} \cdot \mathrm{g}^{-1} \text { aril wt }\right)\end{array}$ & $\begin{array}{c}\text { Pel-3-gl } \\
\left(\mu \mathrm{g} \cdot \mathrm{g}^{-1} \text { aril wt }\right)\end{array}$ & $\begin{array}{c}\text { Total }^{\mathrm{z}} \\
\left(\mu \mathrm{g} \cdot \mathrm{g}^{-1} \text { aril wt }\right)\end{array}$ \\
\hline \multicolumn{7}{|l|}{ Cultivar } \\
\hline Afganski & $53 \mathrm{~B}^{\mathrm{y}}$ & $188 \mathrm{C}$ & $53 \mathrm{BC}$ & $178 \mathrm{~B}$ & $20 \mathrm{AB}$ & $492 \mathrm{C}$ \\
\hline Cranberry & $65 \mathrm{AB}$ & 319 ABC & $13 \mathrm{BC}$ & $36 \mathrm{~B}$ & $0 \mathrm{BC}$ & $433 \mathrm{BC}$ \\
\hline Kaj-acik-anor & $228 \mathrm{~A}$ & $488 \mathrm{AB}$ & $133 \mathrm{~A}$ & $455 \mathrm{~A}$ & $37 \mathrm{~A}$ & $1341 \mathrm{~A}$ \\
\hline Nikitski-ranni & $119 \mathrm{AB}$ & $272 \mathrm{BC}$ & $22 \mathrm{BC}$ & $60 \mathrm{~B}$ & $3 \mathrm{BC}$ & $475 \mathrm{C}$ \\
\hline Salavatski & $18 \mathrm{~B}$ & $140 \mathrm{C}$ & $10 \mathrm{C}$ & $42 \mathrm{~B}$ & $2 \mathrm{C}$ & $213 \mathrm{C}$ \\
\hline RA & $139 \mathrm{~A}$ & $300 \mathrm{~A}$ & $52 \mathrm{~A}$ & $152 \mathrm{~A}$ & $13 \mathrm{~A}$ & $656 \mathrm{~A}$ \\
\hline \multicolumn{7}{|l|}{ Significance } \\
\hline Cultivar & $<0.0001$ & $<0.0001$ & $<0.0001$ & $<0.0001$ & $<0.0001$ & $<0.0001$ \\
\hline Storage & 0.1957 & 0.286 & 0.8922 & 0.7515 & 0.4411 & 0.7958 \\
\hline Cultivar $\times$ storage & 0.0354 & 0.0128 & 0.4697 & 0.7693 & 0.6324 & 0.0711 \\
\hline
\end{tabular}

${ }^{{ }^{z}}$ Total anthocyanin content.

${ }^{\mathrm{y}}$ Values followed by the same letter within a column are not significantly different at $P<0.05$ according to Tukey's honestly significant difference test. De-3-5-digl = delphinidin 3,5-diglucoside; Cy-3-4-digl = cyanidin 3,5-diglucoside; Pet-3-gl = petunidin 3-glucoside; Cy-3-gl = cyanidin 3-glucoside; Pel-3-gl = pelargonidin 3-glucoside. 
Table 6. Rind color of pomegranate fruit of various cultivars, immediately after 3 months of storage in either a controlled atmosphere $\left[\mathrm{CA} ; 5 \% \mathrm{CO}_{2}\right.$ and $3 \% \mathrm{O}_{2}, 5{ }^{\circ} \mathrm{C}$, and $90 \%$ to $95 \%$ relative humidity (RH)] or regular air (RA; $5^{\circ} \mathrm{C}$ and $90 \%$ to $95 \% \mathrm{RH}$ ), harvested from Ponder Farm, Ty Ty, GA, in 2010 and 2011. Rows labeled Cultivar, Storage, and Cultivar $\times$ storage include the $P$ values.

\begin{tabular}{lccc}
\hline & Lightness $^{\mathrm{z}}$ & Hue $^{\mathrm{y}}$ & Chroma $^{\mathrm{x}}$ \\
\hline Cultivar & & & \\
Afganski & $37.6 \mathrm{C}$ & $33.6 \mathrm{~B}$ & $34.9 \mathrm{~B}$ \\
Crab & $40.4 \mathrm{BC}$ & $31.2 \mathrm{~B}$ & $35.7 \mathrm{~B}$ \\
Cranberry & $42.8 \mathrm{~B}$ & $32.4 \mathrm{~B}$ & $39.7 \mathrm{~A}$ \\
Entek-habi-saveh & $49.4 \mathrm{~A}$ & $51.6 \mathrm{~A}$ & $33.3 \mathrm{~B}$ \\
Kaj-acik-anor & $47.8 \mathrm{~A}$ & $53.7 \mathrm{~A}$ & $34.9 \mathrm{~B}$ \\
$\quad$ Salavatski & $49.1 \mathrm{~A}$ & $53.8 \mathrm{~A}$ & $36.5 \mathrm{AB}$ \\
Storage & & & \\
CA & $44.5 \mathrm{~A}$ & $42.9 \mathrm{~A}$ & $35.9 \mathrm{~A}$ \\
RA & $44.5 \mathrm{~A}$ & & $35.7 \mathrm{~A}$ \\
Significance & & & \\
Cultivar & $<0.0001$ & 0.0001 & 0.0001 \\
Storage & 0.975 & 0.0246 & 0.6443 \\
Cultivar $\times$ storage & 0.0266 & & \\
\hline
\end{tabular}

${ }^{\mathrm{z}}$ Degree of darkness or lightness $(0=$ black and $100=$ white $)$.

${ }^{\mathrm{y}}$ Hue angle represents the dominant color wavelength $(0=$ red, $60=$ yellow, and $120=$ green $)$.

${ }^{\mathrm{x}}$ Chroma describes deviation of color from gray $(0=$ gray and $60=$ true color $)$.

${ }^{\mathrm{w}}$ Values followed by the same letter within a column are not significantly different at $P<0.05$ according to Tukey's honestly significant difference test.
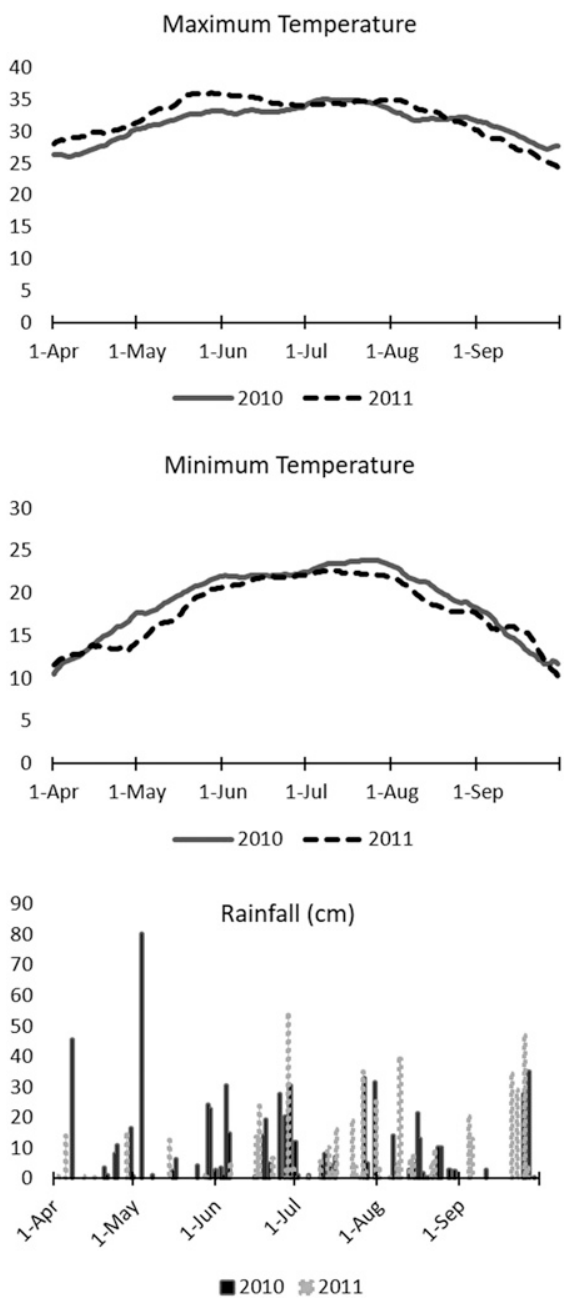

Fig. 1. Seasonal trends of 30-d averages of maximum (top) and minimum (middle) daily temperatures (measured in degrees Celsius, and rainfall events (bottom) (measured in centimeters) from 1 Apr. to 30 Sept. at Tifton, GA in 2010 and 2011. (Source: Climate Data Online at National Centers for Environmental Information; www.ncdc.noaa.gov.) storage. Possibly elevated $\mathrm{CO}_{2}$ concentration and lowered $\mathrm{O}_{2}$ concentration in storage inhibited fungal infection and growth on pomegranate fruit. During storage, enzymatic activity weakens the cell wall, and CI results from cold temperatures. This decaying renders the fruit susceptible to disease damage, more so in RA storage than in CA. Fruit like avocado, papaya, and carambola have been observed to become more susceptible to disease damage in RA than in CA (Wang, 1993). Fungal growth is further suppressed with decrease in storage temperature. However, it is perhaps the high $\mathrm{CO}_{2}$ and low $\mathrm{O}_{2}$ in $\mathrm{CA}$ storage atmosphere that has the greatest impact on decay by inhibiting spore germination and mycelium growth of fungi such as Botrytis cynerea and Penicillium spp. (Conway et al., 2007). CA storage conditions have been observed to suppress pathogen growth and spreading (Yackel et al., 1971). fungal growth by suppressing respiration (Un et al., 2006). An elevated level of $\mathrm{CO}_{2}$ during cold storage reduces CI in fruit (Artés et al., 1996). As in CA storage, fruit under modified storage packaging are subjected to conditions of elevated $\mathrm{CO}_{2}$ and low $\mathrm{O}_{2}$ concentration, resulting in decreased $\mathrm{CI}$ during storage. Modified atmosphere packaging showed lowered CI in carambola (Averrhoa carambola L., cv. B10) fruit, with possible suppression of enzymatic activity (Ali et al., 2004; Wang, 1993). Fruit weight loss has been reported to increase CI symptoms by degrading membrane integrity (Kader and Mitcham, 1999; Opara et al., 2015).

Juice attributes showed no trend in the effects of different storage conditions. In general, juice TSS content has been observed to stay stable during storage and is unaffected by storage condition modifications (Chan et al., 2008; Sayyari et al., 2011). Juice TA was significantly less in 2011 compared with 2010. This could be the result of a considerably hotter and drier weather occurrence in 2011 compared with 2010. Similar observaElevated $\mathrm{CO}_{2}$ level has a profound effect on tions resulting from weather differences during maturity have been reported in pomegranates (Shulman et al., 1984). Our data showed lower TA in CA-stored fruit than in RA-stored fruit in 2011. Comparable results were found in strawberries under CA storage when increased $\mathrm{CO}_{2}$ concentration (and decreased $\mathrm{O}_{2}$ ) led to decreased fruit acidity (Almenar et al., 2006; Gil et al., 1997). Studies have also shown an interaction between cultivars and CA storage conditions when observing fruit juice quality attributes (Bai et al., 2005; Schotsmans et al., 2007).

Flavonoids are not substrates for polyphenol oxidase activity, thus their concentration does not decrease during storage (Roberts, 1960). Various anthocyanins and total anthocyanin content were not different between CA and RA storage. Anthocyanins in apple have also been observed to be stable during storage (Lin et al., 1989; Reay 1998). In blueberries, fruit anthocyanin content has been observed to stay stable during prolonged storage conditions regardless of the air composition (Schotsmans et al., 2007).

Fruit skin lightness $\left(\mathrm{L}^{*}\right)$ did not differ between CA- and RA-stored fruit. These observations are like earlier findings in which fruit rind color characteristics did not change significantly during storage (Artés et al., 1998).

In conclusion, fruit physical quality attributes were affected by storage conditions. The CA-stored fruit had better fruit quality, with a smoother rind, less rind shriveling, less fruit cracking, less CI, and less damage from fungal diseases compared with RA-stored fruit. Thus, CA storage is a better option for pomegranate fruit storage than regular air.

\section{Literature Cited}

Ali, Z.M., L.-H. Chin, M. Marimuthu, and $\mathrm{H}$ Lazan. 2004. Low temperature storage and modified atmosphere packaging of carambola fruit and their effects on ripening related texture changes, wall modification and chilling injury symptoms. Postharvest Biol. Technol. 33:181-192.

Almenar, E., P. Hernández-Muñoz, J.M. Lagarón, R. Catalá, and R. Gavara. 2006. Controlled atmosphere storage of wild strawberry fruit (Fragaria vesca L.). J. Agr. Food Chem. 54:86-91.

Artés, F., J.G. Marín, and J.A. Martínez. 1996. Controlled atmosphere storage of pomegranate. Eur. Food Res. Technol. 203:33-37.

Artés, F., J.A. Tudela, and M.I. Gil. 1998. Improving the keeping quality of pomegranate fruit by intermittent warming. Eur. Food Res. Technol. 207:316-321.

Bai, J., E.A. Baldwin, K.L. Goodner, J.P. Mattheis, and J.K. Brecht. 2005. Response of four apple cultivars to 1-methylcyclopropene treatment and controlled atmosphere storage. HortScience 40:1534-1538.

Barman, K., R. Asrey, and R.K. Pal. 2011. Putrescine and carnauba wax pretreatments alleviate chilling injury, enhance shelf life and preserve pomegranate fruit quality during cold storage. Scientia Hort. 130:795-800.

Basu, A. and K. Penugonda. 2009. Pomegranate juice: A heart-healthy fruit juice. Nutr. Rev. 67:49-56. 
Ben-Arie, R. 1986. The development and control of husk scald on 'Wonderful' pomegranate fruit during storage. J. Amer. Soc. Hort. Sci. 111: 395-399.

Børve, J. and A. Stensvand. 2016. Physiological disorders, bitter rot and other fungal decay of 'Aroma' apple fruit stored in controlled atmosphere. Acta Agr. Scand. B Soil Plant Sci. 66: 461-467.

Caleb, O.J., U.L. Opara, and C.R. Witthuhn. 2012. Modified atmosphere packaging of pomegranate fruit and arils: A review. Food Bioprocess Technol. 5:15-30.

Chan, Z., Q. Wang, X. Xu, X. Meng, G. Qin, B. Li, and S. Tian. 2008. Functions of defense-related proteins and dehydrogenases in resistance response induced by salicylic acid in sweet cherry fruits at different maturity stages. Proteomics 8:4791-4807.

Considine, J. and K. Brown. 1981. Physical aspects of fruit growth: Theoretical analysis of distribution of surface growth forces in fruit in relation to cracking and splitting. Plant Physiol. 68:371-376.

Conway, W.S., W.J. Janisiewicz, B. Leverentz, R.A. Saftner, and M.J. Camp. 2007. Control of blue mold of apple by combining controlled atmosphere, an antagonist mixture, and sodium bicarbonate. Postharvest Biol. Technol. 45: 326-332.

D’Aquino, S., A. Palma, M. Schirra, A. Continella, E. Tribulato, and S. La Malfa. 2010. Influence of film wrapping and fludioxonil application on quality of pomegranate fruit. Postharvest Biol. Technol. 55:121-128.

Díaz-Pérez, J.C. 2019. Transpiration, p. 157-173. In: E.M. Yahia (ed.). Postharvest physiology and biochemistry of fruits and vegetables. Woodhead Publishing, Duxford, UK.

Ding, Z., S. Tian, Y. Wang, B. Li, Z. Chan, J. Han, and Y. Xu. 2006. Physiological response of loquat fruit to different storage conditions and its storability. Postharvest Biol. Technol. 41: $143-150$.

Elyatem, S.M. and A.A. Kader. 1984. Post-harvest physiology and storage behaviour of pomegranate fruits. Scientia Hort. 24:287-298.

Gil, M.I., D.M. Holcroft, and A.A. Kader. 1997. Changes in strawberry anthocyanins and other polyphenols in response to carbon dioxide treatments. J. Agr. Food Chem. 45:1662-1667.

Gómez, P.A. and F. Artés. 2004. Controlled atmospheres enhance postharvest green celery quality. Postharvest Biol. Technol. 34:203-209.

Holland, D., K. Hatib, and I. Bar-Ya'akov. 2009. Pomegranate: Botany, horticulture, breeding. Hort. Rev. 35:127-191.

Kader, A.A. 2003. A summary of CA requirements and recommendations for fruits other than apples and pears. Acta Hort. 600:737-740.

Kader, A.A. and E.J. Mitcham. 1999. Postharvest physiology and storage of tropical and subtropical fruits, p. 78-79. In: S.K. Mitra (ed.). The quarterly review of biology, 74. Oxford University Press, Oxford, UK.

Kader, A.A. and C.B. Watkins. 2000. Modified atmosphere packaging: Toward 2000 and beyond. HortTechnology 10:483-486.

Kays, S.J. 1999. Preharvest factors affecting appearance. Postharvest Biol. Technol. 15:233247.

Kulkarni, A.P. and S.M. Aradhya. 2005. Chemical changes and antioxidant activity in pomegranate arils during fruit development. Food Chem. 93:319-324.

Küpper, W., M. Pekmezci, and J. Henze. 1995. Studies on CA-storage of pomegranate (Punica Granatum L., cv. Hicaz). Acta Hort. 398:101108.

Lidster, P.D., H.J. Lightfoot, and K.B. McRae. 1983. Fruit quality and respiration of 'McIntosh' apples in response to ethylene, very low oxygen and carbon dioxide storage atmospheres. Scientia Hort. 20:71-83.

Lin, T.Y., P.E. Koehler, and R.L. Shewfelt. 1989. Stability of anthocyanins in the skin of Starkrimson apples stored unpackaged, under heat shrinkable wrap and in-package modified atmosphere. J. Food Sci. 54:405-407.

Opara, U.L., J. Atukuri, and O.A. Fawole. 2015. Application of physical and chemical postharvest treatments to enhance storage and shelf life of pomegranate fruit: A review. Scientia Hort. 197:41-49.

Özgen, M., J.P. Palta, and J.D. Smith. 2002. Ripeness stage at harvest influences postharvest life of cranberry fruit: Physiological and anatomical explanations. Postharvest Biol. Technol. 24:291-299.
Palou, L., C.H. Crisosto, and D. Garner. 2007. Combination of postharvest antifungal chemical treatments and controlled atmosphere storage to control gray mold and improve storability of 'Wonderful' pomegranates. Postharvest Biol. Technol. 43:133-142.

Reay, P.F. 1998. The effects of maturity on colour and concentration of pigments in the blush and shaded sides of 'Gala' apple fruit during cool storage. J. Hort. Sci. Biotechnol. 73:841-845.

Roberts, E.A.H. 1960. Effect of glycosylation on the enzymic oxidation and translocation of flavonoids. Nature 185:536.

Sayyari, M., S. Castillo, D. Valero, H.M. DíazMula, and M. Serrano. 2011. Acetyl salicylic acid alleviates chilling injury and maintains nutritive and bioactive compounds and antioxidant activity during postharvest storage of pomegranates. Postharvest Biol. Technol. 60: 136-142.

Schotsmans, W., A. Molan, and B. MacKay. 2007. Controlled atmosphere storage of rabbiteye blueberries enhances postharvest quality aspects. Postharvest Biol. Technol. 44:277-285.

Shulman, Y., L. Fainberstein, and S. Lavee. 1984. Pomegranate fruit development and maturation. J. Hort. Sci. 59:265-274.

Un, Ä.N., J. Ose, E. Almenar, P. Hernández-Muñoz, J.M. Lagarón, R. Catalá, and R. Gavara. 2006. Controlled atmosphere storage of wild strawberry fruit (Fragaria vesca L.). J. Agr. Food Chem. 54:86-91.

Wang, C.Y. 1993. Approaches to reduce chilling injury of fruits and vegetables. Hort. Rev. 15:63-95.

Weerakkody, P., J. Jobling, M.M.V. Infante, and G. Rogers. 2010. The effect of maturity, sunburn and the application of sunscreens on the internal and external qualities of pomegranate fruit grown in Australia. Scientia Hort. 124:5761.

Yackel, W.C., A.I. Nelson, L.S. Wei, and M.P. Steinberg. 1971. Effect of controlled atmosphere on growth of mold on synthetic media and fruit. Appl. Microbiol. 22:513-516.

Yahia, E.M. 2006. Modified and controlled atmospheres for tropical fruits. Stewart Postharvest Rev. 2:1-10. 